\title{
Sistem Pendukung Keputusan Kelompok Dalam Penentuan Lokasi Obyek Wisata Terbaik Di Lombok
}

\author{
Adhie Tri Wahyudi ${ }^{1}$, Yon Pradana $^{2}$, Onggo Saputro ${ }^{3}$ \\ ${ }^{1,2}$ Jurusan S1 Teknik Industri, FT Universitas Setia Budi, J1. Let. Jen. Sutoyo \\ Mojosongo - Surakarta 57127 \\ e-mail: *1adhie.wahyudi@gmail.com, ${ }^{2}$ pradana_025@rocketmail.com, ${ }^{3}$ e_onggo@yahoo.com
}

\begin{abstract}
Abstrak
Lombok adalah salah satu tujuan wisata populer di mancanegara. Ada beberapa tempat wisata favorit di Lombok. Untuk meningkatkan jumlah kesadaran wisatawan dan manajer, pemerintah daerah melakukan penilaian di masing-masing resor. Ada empat partai yang bertugas sebagai penilai atau pengambil keputusan. Penilaian setiap pengambil keputusan masih dilakukan secara manual sehingga penilaiannya masih subjektif. Untuk mengatasi hal ini dibutuhkan sebuah sistem pendukung keputusan kelompok (GDSS). Pengambilan keputusan untuk setiap pengambil keputusan menggunakan sistem integrasi AHP - TOPSIS. Sedangkan proses pengambilan keputusan menggunakan metode BORDA. Proses pengambilan keputusan bersama menghasilkan GILI TRAWANGAN sebagai tujuan wisata terbaik.
\end{abstract}

Kata Kunci : AHP, TOPSIS, BORDA, System

\section{PENDAHULUAN}

Lombok merupakan salah satu destinasi wisata populer di mancanegara. Terdapat beberapa tempat wisata favorit di pulau Lombok seperti : Taman Nasional Gunung Rinjani, Pantai Sekotong, Pantai Kuta Lombok, Pantai Bangko-Bangko, dan lain sebagainya. Pengembangan lokasi wisata dapat menunjang perekonomian daerah, oleh karena itu pemerintah setempat perlu melakukan berbagai pembenahan guna meningkatkan kunjungan wisatawan. Untuk meningkatkan jumlah wisatawan yang berkunjung serta meningkatkan kesadaran pihak pengelola tempat wisata, maka pemerintah daerah mengadakan penilaian pada masing - masing tempat wisata favorit di pulau Lombok. Yang bertindak sebagai penilai adalah Kepala Dinas Pariwisata, Ketua Perkumpulan Agen Wisata, Duta Wisata dan Perwakilan Komunitas Wisatawan selanjutnya disebut sebagai decision maker ( DM ).

Proses penilaian dan pengambilan keputusan dari 4 DM tidak dapat menghasilkan informasi yang akurat karena masih dilakukan dengan cara manual, sehingga penilaian masih bersifat subyektif. Maka, diperlukan suatu system pengambilan keputusan ( Decision Support System / DSS ). DSS dapat membantu 
para decision makers dalam menentukan tempat wisata terbaik yang tepat dan obyektif.

Pada proses pengambilan keputusan bersama (Group Decision Support System ) menggunakan metode BORDA. Metode BORDA dapat menggabungkan keputusan dari beberapa DM sehingga dapat ditarik satu kesimpulan bersama. Sedangkan untuk pengambilan keputusan pada masing - masing penilai menggunakan kombinasi antara metode AHP ( Analytical Hierarchy Process) dan metode TOPSIS (Technique for Order Preference by Similarity to Ideal Solution) karena kombinasi dari metode AHP - TOPSIS dapat menghilangkan subyektifitas penilaian dari masing - masing DM.

\section{METODE PENELITIAN}

\subsection{Metode BORDA}

Ilham \& Mulyana ( 2017 ) menjelaskan bahwa metode Borda merupakan metode voting yang dapat menyelesaikan pengambilan keputusan kelompok, dimana dalam penerapannya masing-masing decision maker memberikan peringkat berdasarkan alternatif pilihan yang ada, proses pemilihan dalam metode Borda, masing-masing voter diberikan alternatif pilihan.

Di misalkan ada $\mathrm{n}$ kandidat pilihan, kandidat atau alternatif pertama diberikan $n$ poin oleh voter atau decision maker. Kandidat kedua diberikan poin n-1 dan seterusnnya. Penentuan pemenang atau alternatif terbaik berdasarkan poin yang tertinggi. Implementasi metode Borda dapat dilihat pada Tabel 1

Tabel 1. Implementasi metode Borda

\begin{tabular}{|c|c|c|c|c|c|c|}
\hline \multirow{2}{*}{$\begin{array}{c}\text { Voter / Decision } \\
\text { Maker }\end{array}$} & \multicolumn{4}{|c|}{ Kandidat / Alternatif Pilihan } & \multirow{2}{*}{ Rangking } & \multirow{2}{*}{ Poin } \\
\cline { 2 - 7 } & $\mathrm{A}$ & $\mathrm{B}$ & $\mathrm{C}$ & $\mathrm{D}$ & & \\
\hline $\mathbf{1}$ & 4 & 2 & 1 & 3 & $\mathbf{1}$ & 3 \\
\hline $\mathbf{2}$ & 3 & 1 & 4 & 2 & $\mathbf{2}$ & 2 \\
\hline $\mathbf{3}$ & 1 & 2 & 3 & 4 & $\mathbf{3}$ & 1 \\
\hline $\begin{array}{c}\text { Perhitungan } \\
\text { Metode BORDA }\end{array}$ & 4 & 7 & 4 & 3 & $\mathbf{4}$ & 0 \\
\hline
\end{tabular}

Masing-masing decision Maker melakukan analisa alternatif pilihan yang ada. Alternatif pilihan dengan peringkat pertama diberikan poin tertinggi, misalnya peringkat pertama diberikan poin 3, peringkat kedua diberikan poin 2, peringkat 3 diberikan poin 1, peringkat keempat diberikan poin 0 . Nilai poin dari hasil pengambilan keputusan masing-masing decision maker dijumlahkan secara 
keseluruhan. Hasil perhitungan metode Borda dengan melibatkan nilai poin alternatif A yaitu $(0+1+3)=4$, alternatif $\mathrm{B}(2+3+2)=7$, alternatif $\mathrm{C}(3+0+1)=4$ dan alternatif $\mathrm{D}(1+2+0)=3$. Berdasarkan hasil perhitungan metode Borda diatas, maka dapat disimpulkan bahwa nilai poin tertinggi adalah alternatif pilihan $\mathrm{B}$.

Pengambilan keputusan kelompok menggunakan metode borda sebagai metode voting untuk menentukan lokasi terbaik berdasarkan preferensi kelompok DM (Susilo \& Azhari 2012). Output proses perhitungan metode AHP - TOPSIS berupa alternatif lokasi teranking untuk masing - masing DM menjadi input proses Borda. Alternatif lokasi diberikan poin N-1 untuk setiap tingkatan ranking. Poin terbesar diperoleh alternatif lokasi dengan ranking teratas paling banyak dari kelompok DM

\subsection{Metode Integrasi AHP - TOPSIS}

Terdapat dua metoda yang digunakan untuk pengolahan data pada masing masing DM yaitu metoda AHP dan metoda TOPSIS. Metoda AHP digunakan untuk mencari bobot prioritas dari masing - masing kriteria dan konsistensinya. Pengujian konsistensi pada data penilaian perbandingan merupakan kelebihan AHP. Pada metode TOPSIS, konsistensi pada nilai perbandingan kepentingan tidak diperhatikan sehingga penilaian yang tidak tepat dari penilai yang tidak kompeten dapat terjadi. Untuk mengatasi hal ini, integrasi antara AHP-TOPSIS dilakukan. Integrasi dapat menjaga tingkat konsistensi data yang akan diproses pada TOPSIS. Integrasi dari kedua metode ini sudah dilakukan oleh Kusnadi \& Dewa (2017) untuk menentukan strategi pada UKM Mikro Teknik. Metode ini dimulai dengan pengisian tabel awal TOPSIS seperti terlihat pada tabel. Perbedaan metode TOPSIS dengan integrasi AHP-TOPSIS adalah data pada tabel 8 bukan merupakan hasil perbandingan kepentingan dengan menggunakan skala interval Likert. Data untuk tabel tersebut didapatkan dari perhitungan AHP melalui persamaan (1) yang digunakan untuk mencari nilai pada tabel 4,sedangkan persamaan (2) digunakan untuk mencari nilai bobot prioritas untuk setiap elemen (kriteria) pada tabel 4, (4), (5), (6).

$$
\begin{array}{r}
a_{i j}{ }^{\prime}=\frac{a i j}{\sum_{i=1}^{n} a_{i j^{\prime}}} \quad \text { dengan } \mathrm{i}, \mathrm{j}=1,2, \ldots . ., \mathrm{n} \\
w_{i}^{T}=\frac{\sum_{j=1}^{n} a_{i j}}{n} \text { dengan } \mathrm{i}, \mathrm{j}=1,2, \ldots . ., \mathrm{n}
\end{array}
$$

Pada tabel 5, dilakukan perkalian antara prioritas relatif dari matriks perbandingan alternatif berdasarkan kriteria dengan bobot hasil perbandingan kriteria 
dengan menggunakan persamaan ( 3 ). Hasil perkalian tersebut dijumlah secara baris sehingga ditemukan prioritas global $(\mathrm{Fj})$.

$$
F_{j}=\sum_{i=1}^{n} a_{i j} \times w_{i}^{T}
$$

Saat penentuan perbandingan kepentingan dilakukan, beberapa penilaian yang tidak konsisten dapat muncul. Menurut Kusnadi \& Dewa ( 2017 ) metode AHP mempunyai metode perhitungan konsistensi untuk mencegah adanya data perbandingan kepentingan dari penilai yang tidak tepat. Perhitungan konsistensi dilakukan dengan menggunakan CR (Consistency Ratio). Hal yang pertama dilakukan adalah mencari nilai eigenvector untuk setiap matriks perbandingan pairwise $(\lambda \max )$ menggunakan persamaan ( 4 ), dimana $n$ adalah banyak elemen matriks, A adalah matriks perbandingan berpasangan, dan adalah matriks bobot prioritas (eigenvector).

$$
\lambda_{\max }=\frac{1}{n} \sum_{i=1}^{n} \frac{\left(A \cdot w^{T}\right) i}{w_{i}^{T}}
$$

Setelah mendapatkan $\lambda \max$, Consistency Index (CI) dapat dihitung dengan menggunakan persamaan (5).

$$
C I=\frac{\lambda_{\max }-n}{n}
$$

Akhirnya, CR untuk setiap matriks perbandingan pair-wise dapat dihitung dengan membagi CI dengan Random Index (RI) sesuai dengan persamaan ( 6 ).

$$
C R=\frac{C I}{I R}
$$

Tabel 2. Nilai Index Random Cosistency ( IR )

\begin{tabular}{cccccccccc}
\hline $\mathbf{N}$ & $\mathbf{2}$ & $\mathbf{3}$ & $\mathbf{4}$ & $\mathbf{5}$ & $\mathbf{6}$ & $\mathbf{7}$ & $\mathbf{8}$ & $\mathbf{9}$ & $\mathbf{1 0}$ \\
\hline $\begin{array}{c}\text { Nilai } \\
\text { IR }\end{array}$ & 0 & 0.58 & 0.90 & 1.12 & 1.24 & 1.32 & 1.41 & 1.45 & 1.49 \\
\hline
\end{tabular}

Apabila nilai $\mathrm{CR} \leq 0.1$ maka dapat disimpulkan matriks perbandingan berpasangan yang dibuat sudah konsisten. Namun jika nilai $C R>0.1$ maka penilaian prioritas harus diperbaiki.

Data pada tabel 3 dipastikan konsisten karena data tersebut merupakan hasil perbandingan kepentingan yang sudah diuji tingkat konsistensinya pada persamaan 
(4), (5), (6). Setelah tabel 5 terisi, perhitungan penentuan keputusan dilakukan dengan menggunakan metode TOPSIS. Hasil dari tabel 5 yang berupa bobot prioritas untuk masing - masing kriteria dikalikan dengan nilai pada tabel 7 yang berupa matriks keputusan ternormalisasi sesuai dengan persamaan (6).

$$
y_{i j}=w_{i} \times r_{i j}
$$

)

$$
\mathrm{W}=\text { bobot prioritas pada tabel } 5
$$

Penentuan solusi selanjutnya adalah mencari nilai $\mathrm{y}_{\max }$ dan $\mathrm{y}_{\min }$ yang didapat dari tabel 8. Nilai $\mathrm{y}_{\max }$ dan $\mathrm{y}_{\min }$ digunakan untuk menentukan jarak $\left(\mathrm{D}^{+} / \mathrm{D}^{-}\right)$antara nilai setiap alternatif dengan matriks solusi ideal positif dan matriks solusi ideal negatif sesuai dengan persamaan (8.1) dan (8.2).

$$
\begin{aligned}
& D^{-}=\sqrt{\sum_{i=1}^{n}\left(y_{i j}-y_{i}^{-}\right)^{2}} \\
& D^{+}=\sqrt{\sum_{i=1}^{n}\left(y_{i}^{+}-y_{i j}\right)^{2}}
\end{aligned}
$$

Langkah terakhir adalah mencari nilai preferensi (Vi) untuk masing - masing alternatif dengan menggunakan persamaan (9). Alternatif solusi dengan nilai tertinggi merupakan solusi yang dipilih.

$$
V_{i}=\frac{D_{i}^{-}}{D_{i}^{-}+D_{i}^{+}}
$$

\section{HASIL DAN PEMBAHASAN}

Proses pengambilan keputusan dilakukan oleh $4 \mathrm{DM}$, dimana proses pengambilan keputusan untuk masing - masing DM dilakukan dengan proses integrasi metode AHP dan TOPSIS. Pada proses perhitungan AHP yang pertama kali dibuat adalah matriks kriteria berpasangan atau perbandingan tingkat kepentingan antar kriteria, seperti yang ditunjukan pada tabel 3 .

Tabel 3. Matriks Kriteria Berpasangan AHP

\begin{tabular}{ccccccc}
\hline Kriteria & $\mathbf{V}$ & $\mathbf{S}$ & $\mathbf{C}$ & $\mathbf{E}$ & $\mathbf{P}$ & $\mathbf{T}$ \\
\hline $\mathbf{V}$ & 1,00 & 0,33 & 2,00 & 0,20 & 0,33 & 3,00 \\
\hline $\mathbf{S}$ & 3,00 & 1,00 & 7,00 & 3,00 & 3,00 & 7,00 \\
\hline $\mathbf{C}$ & 0,50 & 0,14 & 1,00 & 0,33 & 0,14 & 0,50 \\
\hline $\mathbf{E}$ & 5,00 & 0,33 & 3,00 & 1,00 & 0,33 & 2,00 \\
\hline
\end{tabular}




\begin{tabular}{ccccccc}
$\mathbf{P}$ & 3,00 & 0,33 & 7,00 & 3,00 & 1,00 & 5,00 \\
\hline $\mathbf{T}$ & 0,33 & 0,14 & 2,00 & 0,50 & 0,20 & 1,00 \\
\hline Jumlah & 12,83 & 2,29 & 22,00 & 8,03 & 5,01 & 18,50 \\
\hline
\end{tabular}

$\begin{array}{lll}\text { Keterangan: } & \mathrm{V}=\text { Pemandangan } & \mathrm{E}=\text { Kenyamanan } \\ & \mathrm{S}=\text { Keamanan } & \mathrm{P}=\text { Biaya } \\ \mathrm{C}=\text { Kebersihan } & \mathrm{T}=\text { Transportasi }\end{array}$

Langkah selanjutnya adalah mencari nilai vector eigen / bobot prioritas untuk masing - masing kriteria dengan membagi nilai perbandingan antar kriteria pada tabel 3 dengan jumlah pada masing - masing kolom. Lalu dijumlahkan dan dibagi dengan jumlah banyaknya. Hasil untuk vector eigen / bobot prioritas dapat dilihat pada tabel 4.

Tabel 4. Matriks Sintetis AHP

\begin{tabular}{ccccccccc}
\hline & $\mathbf{V}$ & $\mathbf{S}$ & $\mathbf{C}$ & $\mathbf{E}$ & $\mathbf{P}$ & $\mathbf{T}$ & Jumlah & Prioritas \\
\hline $\mathbf{V}$ & 0,078 & 0,146 & 0,091 & 0,025 & 0,067 & 0,162 & 0,568 & 0,095 \\
\hline $\mathbf{S}$ & 0,234 & 0,438 & 0,318 & 0,373 & 0,599 & 0,378 & 2,340 & 0,390 \\
\hline $\mathbf{C}$ & 0,039 & 0,063 & 0,045 & 0,041 & 0,029 & 0,027 & 0,244 & 0,041 \\
\hline $\mathbf{E}$ & 0,390 & 0,146 & 0,136 & 0,124 & 0,067 & 0,108 & 0,971 & 0,162 \\
\hline $\mathbf{P}$ & 0,234 & 0,146 & 0,318 & 0,373 & 0,200 & 0,270 & 1,541 & 0,257 \\
\hline $\mathbf{T}$ & 0,026 & 0,063 & 0,091 & 0,062 & 0,040 & 0,054 & 0,336 & 0,056 \\
\hline
\end{tabular}

Metode AHP memiliki suatu kelebihan dimana terdapat suatu mekanisme pengujian tingkat konsistensi dari penilaian terhadap masing - masing kriteria. Pengujian tersebut juga dapat mengurangi tingkat subjektifitas pada saat proses penilaian. Langkah pertama yang dilakukan adalah mencari nilai bobot prioritas global dengan cara mengalikan nilai perbandingan pada tabel 3 dengan nilai bobot prioritas pada tabel 4. Selanjutnya dijumlahkan pada masing - masing baris, sehingga didapatkan hasil sesuai pada tabel 5.

Tabel 5. Matriks Penjumlahan AHP

\begin{tabular}{cccccccc}
\hline & $\mathbf{V}$ & $\mathbf{S}$ & $\mathbf{C}$ & $\mathbf{E}$ & $\mathbf{P}$ & $\mathbf{T}$ & Jumlah \\
\hline $\mathbf{V}$ & 0,094710452 & 0,130007 & 0,081318 & 0,032365 & 0,085617 & 0,167801 & 0,591818 \\
\hline $\mathbf{S}$ & 0,284131356 & 0,390022 & 0,284612 & 0,485468 & 0,770557 & 0,391536 & 2,606326 \\
\hline $\mathbf{C}$ & 0,047355226 & 0,055717 & 0,040659 & 0,05394 & 0,036693 & 0,027967 & 0,262332 \\
\hline $\mathbf{E}$ & 0,473552261 & 0,130006 & 0,121977 & 0,161823 & 0,085617 & 0,111867 & 1,084841 \\
\hline $\mathbf{P}$ & 0,284131356 & 0,130006 & 0,284612 & 0,485468 & 0,256852 & 0,279668 & 1,720738 \\
\hline $\mathbf{T}$ & 0,031570151 & 0,055717 & 0,081318 & 0,080911 & 0,05137 & 0,055934 & 0,356821 \\
\hline
\end{tabular}


Saat menghitung rasio konsistensi, jumlah pada baris yang didapat dari perhitungan pada tabel 5 dijumlahkan dengan bobot prioritas pada tabel 4 sehingga dihasilkan rasio konsistensi pada tabel 6.

Tabel 6. Rasio Konsistensi

\begin{tabular}{lrrr}
\hline & $\begin{array}{c}\text { Jumlah } \\
\text { pada baris }\end{array}$ & prioritas & \multicolumn{1}{l}{ hasil } \\
\hline $\mathbf{V}$ & 0,59181772 & 0,095 & 0,687 \\
\hline $\mathbf{S}$ & 2,606326261 & 0,390 & 2,996 \\
\hline $\mathbf{C}$ & 0,26233189 & 0,041 & 0,303 \\
\hline $\mathbf{E}$ & 1,084841461 & 0,162 & 1,247 \\
\hline $\mathbf{P}$ & 1,720738016 & 0,257 & 1,978 \\
\hline T & 0,356820783 & 0,056 & 0,413 \\
\hline Total & & & 7,623 \\
\hline
\end{tabular}

Langkah selanjutnya adalah mencari nilai eigen ( $\lambda \max$ ) dengan cara menjumlahkan nilai rasio konsistensi dari masing - masing kriteria lalu dibagi dengan jumlah banyaknya kriteria sehingga dihasilkan nilai 1, 270479.

Setelah memperoleh nilai eigen dilanjutkan dengan mencari nilai CI dan CR dimana nilai eigen dikurangi jumlah banyaknya kriteria lalu dibagi dengan jumlah banyaknya kriteria sehingga dihasilkan nilai CI sebesar -0,78825. Sementara untuk nilai CR, nilai CI yang tadi sudah didapat dibagi dengan nilai index random cosistenct ( sesuai tabel 2 ) sehingga didapatkan hasil sebesar -0,63569. Karena nilai CR pada proses pengujian konsistensi untuk penilaian masing - masing kriteria $\leq 0,1$ maka data penilaian pada masing - masing kriteria konsisten.

Tabel 7. Model Awal Metode TOPSIS

\begin{tabular}{crrrrrr}
\hline \multirow{2}{*}{ Alternatif } & \multicolumn{6}{c}{ Kriteria } \\
& \multicolumn{7}{c}{ View } & Secure & Clean & Comfort & Cost & Transport \\
\hline GR & 0,172 & 0,164 & 0,150 & 0,192 & 0,154 & 0,149 \\
\hline GT & 0,172 & 0,164 & 0,172 & 0,170 & 0,198 & 0,191 \\
\hline GA & 0,134 & 0,117 & 0,193 & 0,149 & 0,066 & 0,106 \\
\hline GM & 0,172 & 0,164 & 0,150 & 0,192 & 0,154 & 0,149 \\
\hline SB & 0,153 & 0,140 & 0,150 & 0,192 & 0,110 & 0,170 \\
\hline TA & 0,153 & 0,164 & 0,150 & 0,149 & 0,176 & 0,170 \\
\hline M & 0,134 & 0,164 & 0,107 & 0,149 & 0,154 & 0,106 \\
\hline BB & 0,153 & 0,140 & 0,150 & 0,106 & 0,176 & 0,128 \\
\hline T & 0,172 & 0,187 & 0,172 & 0,149 & 0,154 & 0,170 \\
\hline
\end{tabular}




\section{Alternatif}

\section{Kriteria}

\begin{tabular}{crrrrrr} 
& View & Secure & Clean & Comfort & Cost & Transport \\
\hline TN & 0,153 & 0,164 & 0,150 & 0,170 & 0,132 & 0,149 \\
\hline TR & 0,172 & 0,117 & 0,150 & 0,128 & 0,198 & 0,149 \\
\hline BM & 0,134 & 0,140 & 0,107 & 0,149 & 0,176 & 0,191 \\
\hline PM & 0,153 & 0,164 & 0,086 & 0,085 & 0,154 & 0,170 \\
\hline WS & 0,134 & 0,140 & 0,107 & 0,128 & 0,154 & 0,170 \\
\hline BK & 0,134 & 0,187 & 0,172 & 0,192 & 0,154 & 0,149 \\
\hline SG & 0,172 & 0,117 & 0,150 & 0,149 & 0,132 & 0,170 \\
\hline GK & 0,172 & 0,164 & 0,172 & 0,128 & 0,176 & 0,149 \\
\hline N & 0,153 & 0,140 & 0,172 & 0,170 & 0,154 & 0,191 \\
\hline GKE & 0,134 & 0,140 & 0,150 & 0,128 & 0,176 & 0,149 \\
\hline TMA & 0,134 & 0,164 & 0,150 & 0,149 & 0,176 & 0,170 \\
\hline BS & 0,153 & 0,187 & 0,150 & 0,192 & 0,154 & 0,170 \\
\hline TS & 0,134 & 0,117 & 0,172 & 0,106 & 0,110 & 0,149 \\
\hline BP & 0,172 & 0,117 & 0,129 & 0,149 & 0,154 & 0,170 \\
\hline MUN & 0,172 & 0,140 & 0,129 & 0,170 & 0,132 & 0,149 \\
\hline TB & 0,172 & 0,164 & 0,150 & 0,149 & 0,088 & 0,106 \\
\hline CB & 0,153 & 0,187 & 0,172 & 0,170 & 0,154 & 0,128 \\
\hline BPE & 0,134 & 0,164 & 0,193 & 0,149 & 0,176 & 0,170 \\
\hline PMA & 0,134 & 0,140 & 0,172 & 0,192 & 0,154 & 0,149 \\
\hline JM & 0,153 & 0,140 & 0,150 & 0,106 & 0,198 & 0,128 \\
\hline PT & 0,172 & 0,164 & 0,150 & 0,149 & 0,176 & 0,149 \\
\hline PSN & 0,153 & 0,164 & 0,150 & 0,128 & 0,154 & 0,128 \\
\hline PSE & 0,172 & 0,187 & 0,150 & 0,149 & 0,154 & 0,128 \\
\hline MHW & 0,172 & 0,117 & 0,107 & 0,106 & 0,176 & 0,170 \\
\hline PN & 0,153 & 0,164 & 0,150 & 0,149 & 0,154 & 0,128 \\
\hline PK & 0,134 & 0,164 & 0,129 & 0,170 & 0,154 & 0,106 \\
\hline PS & 0,153 & 0,117 & 0,150 & 0,192 & 0,154 & 0,191 \\
\hline TK & 0,153 & 0,187 & 0,172 & 0,149 & 0,154 & 0,170 \\
\hline PSU & 0,134 & 0,164 & 0,193 & 0,149 & 0,088 & 0,170 \\
\hline PKL & 0,153 & 0,140 & 0,172 & 0,149 & 0,110 & 0,149 \\
\hline PUS & 0,153 & 0,164 & 0,172 & 0,170 & 0,110 & 0,170 \\
\hline PSG & 0,172 & 0,140 & 0,150 & 0,170 & 0,176 & 0,128 \\
\hline AN & 0,153 & 0,140 & 0,172 & 0,149 & 0,154 & 0,149 \\
\hline & & & & & & \\
\hline
\end{tabular}

Keterangan :

GR = Taman Nasional Gunung Rinjani $\quad$ BS = Air Terjun Benang Stokel

GT = Gili Trawangan $\quad$ TS = Taman Sangkareang

GA $=$ Gili Air

BP = Batu Payung

$\mathrm{GM}=$ Gili Meno

MUN = Museum Negeri Nusa Tenggara

Barat 


$\begin{aligned} \mathrm{SB} & =\text { Pantai Selong Belanak } \\ \mathrm{TA} & =\text { Pantai Tanjung Aan } \\ \mathrm{M} & =\text { Pantai Mawun } \\ \mathrm{BB} & =\text { Pura Batu Bolong } \\ \mathrm{T} & =\text { Pantai Tangsi } \\ \mathrm{TN} & =\text { Taman Narmada } \\ \mathrm{TR} & =\text { Pantai Tanjung Ringgit } \\ \mathrm{BM} & =\text { Bukit Merese } \\ \mathrm{PM} & =\text { Pura Meru } \\ \mathrm{WS} & =\text { Desa Wisata Sade } \\ \mathrm{BK} & =\text { Air Terjun Benang Kelambu } \\ \mathrm{SG} & =\text { Sendang Gile } \\ \mathrm{GK} & =\text { Gili Kondo } \\ \mathrm{N} & =\text { Pantai Nipah } \\ \text { GKE } & =\text { Gili Kedis } \\ \mathrm{TMA} & =\text { Taman Mayura } \\ \text { PSG } & =\text { Pantai Senggigi }\end{aligned}$

$\begin{array}{ll}\text { TB } & =\text { Pantai Tanjung Bloam } \\ \mathrm{CB} & =\text { Candi Bentar } \\ \mathrm{BPE} & =\text { Bukit Pergasingan } \\ \text { PMA } & =\text { Pantai Mawi } \\ \text { JM } & =\text { Air Terjun Jeruk Manis } \\ \text { PT } & =\text { Pantai Tebing } \\ \text { PSN } & =\text { Taman Wisata Pusuk Sembalun } \\ \text { PSE } & =\text { Pantai Semeti } \\ \text { MHW } & =\text { Masjid Hubbul Wathon } \\ \text { PN } & =\text { Pantai Nambung } \\ \text { PK } & =\text { Pantai Kaliantan } \\ \text { PS } & =\text { Pantai Surga } \\ \text { TK } & \text { Air Terjun Tiu Kelep } \\ \text { PSU } & =\text { Pemandian Suranadi } \\ \text { PKL } & \text { Pantai Seger Kuta Lombok } \\ \text { PUS } & =\text { Pura Suranadi } \\ \text { AN } & =\text { Aik Nyet Sesaot }\end{array}$

Nilai bobot prioritas yang didapatkan saat proses perhitungan AHP pada tabel 5, digunakan oleh metode TOPSIS sebagai bobot preferensi untuk masing - masing kriteria. Pada tabel 8 nilai bobot prioritas pada masing - masing kriteria dikalikan dengan nilai pada tabel 7 yaitu matriks ternormalisasi pada masing - masing alternatif.

Tabel 8. Weighted Normalization Decision Matrix

\begin{tabular}{crrrrrr}
\hline \multirow{2}{*}{ Alternatif } & \multicolumn{5}{c}{ Kriteria } \\
\cline { 2 - 7 } & View & Secure & Clean & Comfort & Cost & Transport \\
\hline GR & 0,016 & 0,064 & 0,006 & 0,031 & 0,040 & 0,008 \\
GT & 0,016 & 0,064 & 0,007 & 0,028 & 0,051 & 0,011 \\
GA & 0,013 & 0,046 & 0,008 & 0,024 & 0,017 & 0,006 \\
GM & 0,016 & 0,064 & 0,006 & 0,031 & 0,040 & 0,008 \\
SB & 0,014 & 0,055 & 0,006 & 0,031 & 0,028 & 0,010 \\
TA & 0,014 & 0,064 & 0,006 & 0,024 & 0,045 & 0,010 \\
M & 0,013 & 0,064 & 0,004 & 0,024 & 0,040 & 0,006 \\
BB & 0,014 & 0,055 & 0,006 & 0,017 & 0,045 & 0,007 \\
T & 0,016 & 0,073 & 0,007 & 0,024 & 0,040 & 0,010 \\
TN & 0,014 & 0,064 & 0,006 & 0,028 & 0,034 & 0,008 \\
TR & 0,016 & 0,046 & 0,006 & 0,021 & 0,051 & 0,008 \\
BM & 0,013 & 0,055 & 0,004 & 0,024 & 0,045 & 0,011 \\
PM & 0,014 & 0,064 & 0,003 & 0,014 & 0,040 & 0,010 \\
WS & 0,013 & 0,055 & 0,004 & 0,021 & 0,040 & 0,010 \\
BK & 0,013 & 0,073 & 0,007 & 0,031 & 0,040 & 0,008 \\
SG & 0,016 & 0,046 & 0,006 & 0,024 & 0,034 & 0,010 \\
GK & 0,016 & 0,064 & 0,007 & 0,021 & 0,045 & 0,008 \\
N & 0,014 & 0,055 & 0,007 & 0,028 & 0,040 & 0,011 \\
\hline & & & & & & \\
\hline
\end{tabular}




\begin{tabular}{crrrrrr}
\hline \multirow{2}{*}{ Alternatif } & \multicolumn{5}{c}{ Kriteria } \\
\cline { 2 - 7 } & View & Secure & Clean & Comfort & Cost & Transport \\
\hline GKE & 0,013 & 0,055 & 0,006 & 0,021 & 0,045 & 0,008 \\
TMA & 0,013 & 0,064 & 0,006 & 0,024 & 0,045 & 0,010 \\
BS & 0,014 & 0,073 & 0,006 & 0,031 & 0,040 & 0,010 \\
TS & 0,013 & 0,046 & 0,007 & 0,017 & 0,028 & 0,008 \\
BP & 0,016 & 0,046 & 0,005 & 0,024 & 0,040 & 0,010 \\
MUN & 0,016 & 0,055 & 0,005 & 0,028 & 0,034 & 0,008 \\
TB & 0,016 & 0,064 & 0,006 & 0,024 & 0,023 & 0,006 \\
CB & 0,014 & 0,073 & 0,007 & 0,028 & 0,040 & 0,007 \\
BPE & 0,013 & 0,064 & 0,008 & 0,024 & 0,045 & 0,010 \\
PMA & 0,013 & 0,055 & 0,007 & 0,031 & 0,040 & 0,008 \\
JM & 0,014 & 0,055 & 0,006 & 0,017 & 0,051 & 0,007 \\
PT & 0,016 & 0,064 & 0,006 & 0,024 & 0,045 & 0,008 \\
PSN & 0,014 & 0,064 & 0,006 & 0,021 & 0,040 & 0,007 \\
PSE & 0,016 & 0,073 & 0,006 & 0,024 & 0,040 & 0,007 \\
MHW & 0,016 & 0,046 & 0,004 & 0,017 & 0,045 & 0,010 \\
PN & 0,014 & 0,064 & 0,006 & 0,024 & 0,040 & 0,007 \\
PK & 0,013 & 0,064 & 0,005 & 0,028 & 0,040 & 0,006 \\
PS & 0,014 & 0,046 & 0,006 & 0,031 & 0,040 & 0,011 \\
TK & 0,014 & 0,073 & 0,007 & 0,024 & 0,040 & 0,010 \\
PSU & 0,013 & 0,064 & 0,008 & 0,024 & 0,023 & 0,010 \\
PKL & 0,014 & 0,055 & 0,007 & 0,024 & 0,028 & 0,008 \\
PUS & 0,014 & 0,064 & 0,007 & 0,028 & 0,028 & 0,010 \\
PSG & 0,016 & 0,055 & 0,006 & 0,028 & 0,045 & 0,007 \\
AN & 0,014 & 0,055 & 0,007 & 0,024 & 0,040 & 0,008 \\
\hline & & & & & & \\
\hline
\end{tabular}

Setelah didapatkan matriks normalisasi terbobot, langkah selanjutnya adalah menentukan nilai ideal positif $\left(\mathrm{A}^{+}\right)$dan nilai ideal negatif $\left(\mathrm{A}^{-}\right)$dimana nilai positif adalah nilai yang paling besar pada masing - masing kolom dan nilai negatif adalah nilai yang paling minimum pada masing - masing kolom.

$$
\begin{array}{ll}
\text { Nilai } A^{+}=(0,016 ; 0,073 ; 0,008 ; 0,031 ; 0,051 ; 0,011) \\
\text { Nilai } A^{-} & =\quad(0,013 ; 0,046 ; 0,003 ; 0,014 ; 0,017 ; 0,006)
\end{array}
$$

Langkah selanjutnya adalah nilai pada tabel 7 dikurangkan dengan nilai $\mathrm{A}^{+}$ dan nilai $\mathrm{A}^{-}$pada masing - masing kolom lalu dipangkatkan 2 dan dijumlahkan untuk masing - masing alternatif. Setelah itu, nilai tersebut diakar pada masing masing alternatif untuk mencari nilai - nilai jarak alternatif terhadap solusi ideal positif $\mathrm{D}^{+}$dan solusi ideal negatif $\mathrm{D}^{-}$. 
Tabel 9. Nilai Jarak Alternatif Terhadap Solusi Optimal

\begin{tabular}{cccccccccc}
\hline $\mathbf{D}+$ & $\mathbf{D}-$ & $\mathbf{D}+$ & $\mathbf{D}-$ & $\mathbf{D}+$ & $\mathbf{D}-$ & $\mathbf{D}+$ & $\mathbf{D}-$ & $\mathbf{D}+$ & $\mathbf{D}-$ \\
\hline $\mathbf{0 , 0 1 5}$ & 0,034 & 0,030 & 0,035 & 0,015 & 0,040 & 0,019 & 0,030 & 0,021 & 0,033 \\
$\mathbf{0 , 0 1 5}$ & 0,041 & 0,024 & 0,031 & 0,039 & 0,013 & 0,015 & 0,037 & 0,024 & 0,027 \\
$\mathbf{0 , 0 4 5}$ & 0,012 & 0,025 & 0,029 & 0,032 & 0,025 & 0,033 & 0,029 & & \\
$\mathbf{0 , 0 1 7}$ & 0,034 & 0,026 & 0,025 & 0,027 & 0,024 & 0,018 & 0,031 & & \\
$\mathbf{0 , 0 2 9}$ & 0,023 & 0,015 & 0,040 & 0,031 & 0,023 & 0,017 & 0,033 & & \\
$\mathbf{0 , 0 1 6}$ & 0,035 & 0,034 & 0,020 & 0,014 & 0,038 & 0,032 & 0,029 & & \\
$\mathbf{0 , 0 1 8}$ & 0,031 & 0,017 & 0,035 & 0,016 & 0,036 & 0,016 & 0,037 & & \\
$\mathbf{0 , 0 2 5}$ & 0,030 & 0,024 & 0,028 & 0,023 & 0,030 & 0,032 & 0,022 & & \\
$\mathbf{0 , 0 1 6}$ & 0,037 & 0,024 & 0,031 & 0,024 & 0,036 & 0,031 & 0,018 & & \\
$\mathbf{0 , 0 2 1}$ & 0,029 & 0,016 & 0,035 & 0,015 & 0,036 & 0,026 & 0,026 & & \\
\hline
\end{tabular}

Setelah memperoleh nilai-nilai jarak alternatif terhadap solusi ideal positif dan negatif, maka langkah terakhirnya adalah menentukan nilai preferensi (Vi) setiap alternatif. Nilai $\mathrm{D}^{-}$pada tabel 9 dibagi dengan nilai $\mathrm{D}^{+}$ditambah dengan nilai $\mathrm{D}^{-}$ sehingga dihasilkan data seperti yang diperlihatkan di tabel 10 .

Tabel 10. Alternatif Terangking Sesuai Nilai Preferensi

\begin{tabular}{cc}
\hline Alternatif & $\mathbf{V}$ \\
\hline GT & 0,739591 \\
CB & 0,733804 \\
BK & 0,732089 \\
BS & 0,725464 \\
PSE & 0,711973 \\
PT & 0,698721 \\
GR & 0,697276 \\
T & 0,695803 \\
TK & 0,693765 \\
TA & 0,686989 \\
BPE & 0,684995 \\
TMA & 0,682711 \\
GK & 0,670608 \\
GM & 0,669776 \\
PK & 0,661193 \\
PN & 0,637191 \\
\hline M & 0,636025 \\
\hline PSG & 0,615466 \\
\hline
\end{tabular}




\begin{tabular}{cc}
\hline Alternatif & $\mathbf{V}$ \\
\hline PSN & 0,609649 \\
JM & 0,59654 \\
TN & 0,573118 \\
BM & 0,572329 \\
GKE & 0,565234 \\
\hline PMA & 0,563718 \\
BB & 0,550331 \\
\hline PM & 0,539189 \\
\hline N & 0,53759 \\
\hline TR & 0,534344 \\
\hline AN & 0,527002 \\
\hline PUS & 0,493896 \\
\hline WS & 0,492571 \\
\hline MUN & 0,475415 \\
\hline PS & 0,475013 \\
\hline MHW & 0,467181 \\
\hline BP & 0,440801 \\
\hline SB & 0,436674 \\
\hline TB & 0,421644 \\
\hline PSU & 0,408408 \\
\hline SG & 0,37257 \\
\hline PKL & 0,372068 \\
\hline TS & 0,242684 \\
\hline GA & 0,214222 \\
\hline &
\end{tabular}

Hasil pada tabel 10 merupakan hasil alternatif terangking dari salah satu DM. Hasil alternatif terangking yang dihasilkan oleh DM lainnya melalui proses integrasi sistem AHP - TOPSIS dijadikan satu menjadi model awal matriks BORDA sesuai dengan tabel 11.

Tabel 11. Model Awal Metode BORDA

\begin{tabular}{cccccc}
\hline \multirow{2}{*}{ Rangking } & \multirow{3}{*}{ Bobot } & \multicolumn{4}{c}{ DM } \\
\cline { 3 - 6 } & & DM 1 & DM 2 & DM 3 & DM 4 \\
\cline { 3 - 6 } & & 2 & 1 & 1 & 1 \\
\hline $\mathbf{1}$ & 42 & GT & CB & BK & GT \\
\hline $\mathbf{2}$ & 41 & CB & BK & GT & CB \\
$\mathbf{3}$ & 40 & BK & PSE & BS & BS \\
$\mathbf{4}$ & 39 & BS & GT & GR & PT \\
$\mathbf{5}$ & 38 & PSE & PT & CB & BK \\
\hline $\mathbf{6}$ & 37 & PT & GR & PSE & T \\
\hline $\mathbf{7}$ & 36 & GR & TK & TK & PSE \\
\hline $\mathbf{8}$ & 35 & T & BS & T & GR \\
\hline
\end{tabular}




\begin{tabular}{|c|c|c|c|c|c|}
\hline \multirow{3}{*}{ Rangking } & \multirow{3}{*}{ Bobot } & \multicolumn{4}{|c|}{ DM } \\
\hline & & DM 1 & DM 2 & DM 3 & DM 4 \\
\hline & & 2 & 1 & 1 & 1 \\
\hline 9 & 34 & TK & $\mathrm{T}$ & PT & TA \\
\hline 10 & 33 & TA & BPE & TA & TMA \\
\hline 11 & 32 & BPE & TMA & BPE & GM \\
\hline 12 & 31 & TMA & GK & PK & BPE \\
\hline 13 & 30 & GK & TA & GK & PK \\
\hline 14 & 29 & GM & PSG & $\mathrm{M}$ & TK \\
\hline 15 & 28 & PK & $\mathrm{PN}$ & TMA & GK \\
\hline 16 & 27 & $\mathrm{PN}$ & GM & PSG & $\mathrm{JM}$ \\
\hline 17 & 26 & $\mathrm{M}$ & PS & GM & PS \\
\hline 18 & 25 & PSG & PK & $\mathrm{TN}$ & $\mathrm{M}$ \\
\hline 19 & 24 & PS & M & PN & PSG \\
\hline 20 & 23 & JM & GKE & $\mathrm{JM}$ & $\mathrm{PN}$ \\
\hline 21 & 22 & $\mathrm{TN}$ & JM & PS & $\mathrm{BM}$ \\
\hline 22 & 21 & $\mathrm{BM}$ & $\mathrm{N}$ & $\mathrm{BM}$ & TR \\
\hline 23 & 20 & GKE & TN & TR & BB \\
\hline 24 & 19 & PMA & AN & $\mathrm{N}$ & $\mathrm{TN}$ \\
\hline 25 & 18 & BB & TR & $\mathrm{BB}$ & PMA \\
\hline 26 & 17 & PM & $\mathrm{BM}$ & PM & PM \\
\hline 27 & 16 & $\mathrm{~N}$ & $\mathrm{BB}$ & GKE & GKE \\
\hline 28 & 15 & TR & PM & PMA & AN \\
\hline 29 & 14 & $\mathrm{AN}$ & PMA & AN & $\mathrm{N}$ \\
\hline 30 & 13 & PUS & MUN & PSN & SB \\
\hline 31 & 12 & SB & PUS & MUN & PUS \\
\hline 32 & 11 & MUN & PSN & SB & MHW \\
\hline 33 & 10 & PSN & SB & PUS & MUN \\
\hline 34 & 9 & MHW & BP & WS & PSN \\
\hline 35 & 8 & BP & WS & MHW & BP \\
\hline 36 & 7 & WS & MHW & TB & WS \\
\hline 37 & 6 & $\mathrm{~TB}$ & PSU & BP & $\mathrm{SG}$ \\
\hline 38 & 5 & PSU & $\mathrm{SG}$ & PSE & PSU \\
\hline 39 & 4 & $\mathrm{SG}$ & TB & TS & PSE \\
\hline 40 & 3 & PSE & GA & GA & TB \\
\hline 41 & 2 & $\mathrm{TS}$ & PSE & $\mathrm{SG}$ & TS \\
\hline 42 & 1 & GA & TS & PSU & GA \\
\hline
\end{tabular}

Langkah terakhir adalah mengkalikan antara bobot rangking dengan bobot untuk masing - masing DM sesuai dengan posisi masing - masing alternatif setelah diolah melalui metode integrasi AHP - TOPSIS. Hasil alternatif terbaik untuk GDSS dalam menentukan tempat wisata terbaik di Lombok adalah Gili Trawangan dengan nilai akhir 206. Untuk hasil alternatif terangking secara lengkap dapat dilihat pada tabel 12 . 
Tabel 12. Alternatif Terangking Sesuai metode BORDA

\begin{tabular}{|c|c|}
\hline Alternatif & V akhir \\
\hline GT & 206 \\
\hline CB & 203 \\
\hline BK & 201 \\
\hline BS & 193 \\
\hline PSE & 189 \\
\hline PT & 185 \\
\hline GR & 183 \\
\hline $\mathbf{T}$ & 176 \\
\hline TK & 169 \\
\hline TA & 163 \\
\hline BPE & 160 \\
\hline TMA & 155 \\
\hline GK & 149 \\
\hline GM & 143 \\
\hline PK & 142 \\
\hline PN & 129 \\
\hline $\mathbf{M}$ & 130 \\
\hline PSG & 130 \\
\hline PS & 122 \\
\hline JM & 118 \\
\hline TN & 108 \\
\hline BM & 102 \\
\hline GKE & 95 \\
\hline PMA & 85 \\
\hline BB & 90 \\
\hline PM & 83 \\
\hline $\mathbf{N}$ & 86 \\
\hline TR & 89 \\
\hline $\mathbf{A N}$ & 76 \\
\hline PUS & 60 \\
\hline SB & 58 \\
\hline MUN & 57 \\
\hline PSN & 53 \\
\hline MHW & 44 \\
\hline BP & 39 \\
\hline WS & 38 \\
\hline TB & 26 \\
\hline PSU & 22 \\
\hline SG & 21 \\
\hline PSE & 17 \\
\hline TS & 11 \\
\hline
\end{tabular}




\begin{tabular}{cc}
\hline Alternatif & V akhir \\
\hline GA & 9 \\
\hline
\end{tabular}

\section{KESIMPULAN}

Kesimpulan yang didapat dari hasil penelitian dengan judul Sistem Pendukung Keputusan Kelompok Dalam Menentukan Obyek Wisata Terbaik Di Lombok adalah :

1. Penentuan tempat wisata terbaik untuk masing - masing DM dilakukan dengan menggunakan metode AHP - TOPSIS. Hasil alternatif terangking dari masing - masing DM yang berbeda dapat diakomodasi dengan menggunakan metode BORDA.

2. Berdasarkan hasil analisis yang telah dilakukan diperoleh alternative terangking yang menempatkan Gili Trawangan sebagai tempat wisata terbaik.

3. Metode yang digunakan mampu mengurangi tingkat subjektifitas dalam proses pengambilan keputusan karena melibatkan beberapa prosedur penilaian yang harus dilakukan dengan baik.

\section{SARAN}

Penulis menyarankan dalam penelitian berikutnya, bobot untuk rangking dan bobot untuk masing - masing DM dapat ditentukan secara obyektif agar alternatif terangking yang dihasilkan dapat lebih akurat.

\section{DAFTAR PUSTAKA}

Ilham, D.N. \& Mulyana, S., 2017. Sistem Pendukung Keputusan Kelompok Pemilihan Tempat PKL Mahasiswa dengan Menggunakan Metode AHP dan Borda. IJCCS, 11(1), pp.55-66.

Kusnadi, K. \& Dewa, P.K., 2017. Strategi Pembuatan Keputusan Memenuhi Permintaan dengan Mempertimbangkan Multi Kriteria pada UKM Mikro Teknik. In Seminar dan Konferensi Nasional IDEC 2017. pp. 266-275.

Putri, R. E., 2016. Sistem Pendukung Keputusan Pemilihan Lokasi Mendirikan Usaha Kuliner di kota Nganjuk Menggunakan Metode Topsis berbasis Webgis. J-Intech, 4(1), pp.123-128.

Susilo, B. \& Azhari, 2012. GDSS Penentuan Lokasi Shelter Baru Transjogja Menggunakan Metode Brown-Gibson dan Borda. IJCCS, 6(2), pp.57-66. 